\title{
Determinação precoce do sexo fetal pela análise do DNA no plasma materno
}

\author{
Early determination of gender by analysis of fetal DNA in maternal plasma
}

\begin{abstract}
Ciro Dresch Martinhago ${ }^{1}$, Ricardo Manoel de Oliveira ${ }^{2}$, Maria do Carmo Tomitão Canas ${ }^{3}$, Laura Diniz Vagnini ${ }^{4}$, João Batista Alcantara Oliveira ${ }^{5}$, Claudia Guilhermino Petersen ${ }^{6}$, José Gonçalves Franco Junior ${ }^{7}$
\end{abstract}

\section{RESUMO}

Objetivo: avaliar a possibilidade do diagnóstico precoce do sexo fetal no plasma materno pela técnica da reação em cadeia da polimerase em tempo real (PCR em tempo real) a partir da $5^{\mathrm{a}}$ semana de gestação. Métodos: nesse estudo prospectivo foi coletado sangue periférico de gestantes com feto único a partir da $5^{\mathrm{a}}$ semana de gestação. Após centrifugação do sangue, $0,4 \mathrm{~mL}$ de plasma foi separado para extração de DNA fetal. O DNA foi analisado em duplicata por PCR em tempo real para duas regiões genômicas (uma do cromossomo Y e outra comum a ambos os sexos) pelo método de TaqMan ${ }^{\circledR}$, o qual utiliza um par de primers e uma sonda fluorescente. Foram excluídos da amostragem os casos que evoluíram para aborto. Para o cálculo da sensibilidade e especificidade, usamos o método de comparação com padrão-ouro, que foi o sexo ao nascimento. Resultados: foram realizados 79 exames de DNA fetal no plasma materno de 52 gestantes. O resultado dos exames foi comparado com o sexo da criança após o parto. O índice de acerto conforme a idade gestacional foi de $92,6 \%$ (25 de 27 casos) na $5^{\text {a }}$ semana, conferindo sensibilidade de $87 \%$ e 95,6\% (22 de 23 casos) na $6^{\text {a }}$ semana, com sensibilidade de $92 \%$. A partir da $7^{\text {a }}$ semana de gestação o acerto foi em 100\% (29 de 29 casos). A especificidade foi de $100 \%$ independente da idade gestacional. Conclusões: a técnica de PCR em tempo real para detecção do sexo fetal a partir da $5^{\mathrm{a}}$ semana no plasma materno possui boa sensibilidade e excelente especificidade. Houve concordância do resultado em $100 \%$ dos casos em que o diagnóstico foi masculino, independente da idade gestacional, e no caso de feminino, a partir da $7^{\mathrm{a}}$ semana de gestação.

PALAVRAS-CHAVE: Determinação do sexo (Análise); Reação em cadeia da polimerase/métodos; Diagnóstico pré-natal; Idade gestacional

\section{ABSTRACT}

Purpose: to verify the viability of early diagnosis of fetal gender in maternal plasma by the real-time polymerase chain reaction (real-time PCR) starting at the 5th week of pregnancy. Methods: peripheral blood was collected from pregnant women with single fetus starting at the 5 th week of gestation. After centrifugation, $0.4 \mathrm{~mL}$ plasma was separated for fetal DNA extraction. The DNA was analyzed in duplicate by real-time PCR for two genomic regions, one of the Y chromosome and the other common to both sexes, through the TaqMan ${ }^{\circledR}$ method, which uses a pair of primers and a fluorescent probe. Patients who aborted were excluded. Results: a total of 79 determinations of fetal DNA in maternal plasma were performed in 52 pregnant women. The results of the determinations were compared to fetal gender after delivery. Accuracy according to gestational age was $92.6 \%$ (25 of 27 cases) at 5 weeks with 87\% sensitivity, and 95.6\% (22 of 23 cases) at 6 weeks with $92 \%$ sensitivity. Starting at the 7 th week of pregnancy, accuracy was 100\% (29 of 29 cases). Specificity was $100 \%$ regardless of gestational age. Conclusion: real-time PCR for the detection of fetal gender in maternal plasma starting at the 5 th week of gestation has good sensitivity and excellent specificity. There was agreement of the results in $100 \%$ of the cases in which male gender was diagnosed, regardless of gestational age, and from the 7 th week of gestation for female gender diagnosis.

KEYWORDS: Sex determination (Analysis); Polymerase chain reaction/methods; Pre-natal diagnosis; Gestational age

\footnotetext{
Trabalho realizado no Centro Paulista de Diagnóstico e Pesquisa - CPDP - Ribeirão Preto (SP) - Brasil

1 Médico geneticista do CPDP - Centro Paulista de Diagnóstico e Pesquisa - Ribeirão Preto (SP) - Brasil; Doutorando do Programa de Pós-Graduação em Ginecologia, Obstetrícia e Mastologia da Faculdade de Medicina de Botucatu - Universidade Estadual Paulista "Julio Mesquita Filho" - UNESP Botucatu (SP) - Brasil.

2 Diretor do RDO Diagnósticos Médicos - São Paulo (SP) - Brasil.

3 Bióloga do CPDP - Centro Paulista de Diagnóstico e Pesquisa - Ribeirão Preto (SP), Brasil.

4 Bioquímica do CPDP - Centro Paulista de Diagnóstico e Pesquisa - Ribeirão Preto (SP), Brasil.

5 Médico do Centro de Reprodução Humana - Prof. Franco Junior - Ribeirão Preto (SP), Brasil.

6 Embriologista do Centro de Reprodução Humana - Prof. Franco Junior - Ribeirão Preto (SP), Brasil.

7 Diretor do Centro de Reprodução Humana - Prof. Franco Junior - Ribeirão Preto (SP), Brasil.

Correspondência: José Gonçalves Franco Junior

Av. Professor João Fiusa, 689 - Alto da Boa Vista - 14025-310 - Ribeirão Preto - SP - e-mail: franco@crh.com.br / crh@crh.com.br

Recebido em: 6/12/2005

Aceito com modificações em: 31/3/2006
}

Rev Bras Ginecol Obstet. 2006;28(3): 190-4 
Introdução

Desde $1966^{1}$, com a demonstração de que a constituição cromossômica de um feto podia ser determinada pela análise da cultura das células do líquido amniótico, o diagnóstico pré-natal vem despertando grande interesse da comunidade médica. Após quase 40 anos, grandes avanços na área de diagnóstico pré-natal têm sido alcançados, e cada vez mais se estudam métodos não invasivos que propiciem o diagnóstico precoce de distúrbios fetais. Na área da biologia molecular já é possivel o diagnóstico de inúmeros distúrbios genéticos, sejam herdados ou não ${ }^{2-5}$.

A passagem de células fetais para o sangue materno é fenômeno bem conhecido, e já se imaginava que essa fonte de material fetal poderia ser ferramenta para detecção de anormalidades relacionadas ao feto ${ }^{6}$. Em 1997, foi descrita pela primeira vez a presença de DNA fetal no plasma e soro maternos ${ }^{7}$. No mesmo trabalho se destaca a importância do achado de uma fonte de material fetal no sangue materno, com possivel aplicação como exame diagnóstico não invasivo de distúrbios fetais como as cromossomopatias (aneuploidias fetais), distúrbios genéticos herdados paternalmente ou de algumas doenças genéticas com modo de herança autossômica recessiva. Na ocasião, a detecção do DNA fetal foi confirmada pela presença de uma região do cromossomo Y. As gestantes com um feto do sexo masculino apresentavam o exame positivo. Já na gravidez com feto feminino os exames eram negativos. Aproximadamente um ano depois, os mesmos pesquisadores conseguiram quantificar o DNA fetal em relação ao DNA materno, por meio de nova tecnologia em biologia molecular com a reação em cadeia da polimerase em tempo real (PCR em tempo real) ${ }^{8}$. Do plasma das gestantes foi extraído o DNA fetal, sendo analisado em PCR por meio da identificação de duas regiões genômicas, uma no cromossomo Y e outra em região comum para os cromossomos $\mathrm{X}$ e Y denominada de beta-globina. A amplificação da região da beta-globina serve como controle positivo da reação, já a região do cromossomo Y é detectada apenas quando o feto é do sexo masculino. O diagnóstico do feto do sexo feminino é feito por exclusão. A metodologia aplicada para se quantificar o DNA fetal foi efetuada por meio de "curva padrão", na qual se usa um DNA de feto do sexo masculino e, a partir desse, fazem-se diluições que no caso do trabalho foram de 1.000 até uma única cópia do cromossomo $\mathrm{Y}^{8}$. Portanto, em cada reação foram usadas essas curvas-padrão versus o DNA extraído do plasma das gestantes com a sub- seqüente quantificação. Além disso, os autores conseguiram demonstrar que no primeiro e segundo trimestres de gestação, o DNA fetal corresponde a uma concentração em média de $3,4 \%$ de todo o DNA presente no plasma, já no terceiro trimestre de gestação essa concentração chega a $6,2 \%{ }^{8,9}$.

Recentemente, foi demonstrado que mulheres gestando fetos com aneuploidia, principalmente a trissomia do cromossomo 21 (sindrome de Down) ou do cromossomo 13 (síndrome de Patau), apresentavam concentração de DNA fetal muito maior que as mulheres que gestavam fetos sem o mesmo distúrbio ${ }^{10-12}$. Contudo, esses dados são preliminares, pois o número de amostras ainda é pequeno.

Atualmente, usando-se a técnica de PCR em tempo real, a grande maioria dos trabalhos tem mostrado sensibilidade e especificidade de $100 \%$ para o diagnóstico do sexo fetal no primeiro trimestre de gestação ${ }^{13-16}$. Esses trabalhos, porém, priorizaram a detecção do DNA fetal a partir da $7^{\text {a }}$ semana de gestação, havendo dúvida se seria possivel a detecção em idades gestacionais mais precoces. Dessa forma, o objetivo deste trabalho foi avaliar a viabilidade do diagnóstico precoce do sexo fetal no plasma materno pela técnica de PCR em tempo real, a partir da $5^{\mathrm{a}}$ semana de gestação.

\section{Métodos}

Nesse estudo prospectivo foram incluídas gestantes a partir da $5^{\mathrm{a}}$ semana que engravidaram de feto único por meio de fertilização in vitro no Centro de Reprodução Humana Prof. Franco Junior. Após esclarecimentos sobre a pesquisa, as gestantes interessadas em participar assinaram termo de consentimento livre e esclarecido, o qual foi submetido e aprovado pelo Comitê de Ética e Pesquisa da Universidade de Ribeirão Preto (UNAERP). O sexo fetal determinado foi confirmado junto aos pais após o nascimento da criança.

A metodologia envolveu a coleta de $10 \mathrm{~mL}$ de sangue periférico materno em tubos contendo o anticoagulante EDTA e centrifugados para a separação do plasma. O plasma obtido foi colocado em tubo de PCR e congelado à temperatura de $-20^{\circ} \mathrm{C}$. Caso a manipulação imediata do plasma não fosse possivel, as amostras seriam estocadas em geladeira por no máximo 48 horas. Posteriormente, os tubos de PCR contendo o plasma materno foram centrifugados novamente e todo o material sobrenadante foi então colocado em novos tubos de PCR, dos quais foi retirado 0,4 $\mathrm{mL}$ para extrair o DNA fetal. A extração de DNA foi realizada por 
meio de kit comercial (QIAamp Blood Mini Kit Qiagen, GmbH, Alemanha) com protocolo sugerido pelo fabricante. Todo o processo foi executado por indivíduo do sexo feminino para evitar possíveis contaminações exógenas com DNA masculino.

As reações foram realizadas em máquina de PCR em tempo real (7500 Real Time PCR System - Applied Biosystems, Foster City, CA, USA) utilizando o sistema TaqMan ${ }^{\circledR}$ para detecção do produto de amplificação. O princípio do sistema utilizado na PCR em tempo real consistiu na combinação de um termociclador com a detecção de fluorescência emitida em cada ciclo. O método de TaqMan $^{\circledR}$ utiliza uma sonda marcada com uma molécula fluorescente (fluoróforo) e outra de apagamento intramolecular (quencher) além do par de oligos iniciadores (primers) que se utilizam na PCR comum. A sonda é constituída de uma seqüênciaalvo que está entre os dois oligos iniciadores. Enquanto a sonda está livre em solução, o fluoróforo e o quencher que ficam nas extremidades da sonda só emitem sinal quando são separados por meio da clivagem da sonda pela enzima Taq ${ }^{\circledR}$ DNA polimerase durante a reação. Portanto, durante a reação, quando as sondas se ligam na seqüência-alvo, o fluoróforo e o quencher são separados, e a fluorescência pode ser mensurada pela máquina $8,17,18$.

O DNA materno-fetal foi submetido à análise de duas regiões genômicas, uma comum para ambos os sexos (beta-globina) e outra especifica de uma região do cromossomo Y (DYS-14). A reação da betaglobina serve como controle de amplificação e evita resultado falso-negativo devido a inibidores da reação de PCR. Já a reação com DYS-14 amplifica uma região de 147 pares de bases quando o DNA fetal é do sexo masculino. Quando o sexo fetal feminino é diagnosticado, ocorre a amplificação da região controle (beta-globina) e não ocorre o sinal de amplificação da região do cromossomo Y, ou seja, o diagnóstico é feito por exclusão do sexo masculino. No caso de diagnóstico do feto masculino, obrigatoriamente as duas regiões mostram amplificação. Para maior segurança e eficiência, as duas regiões foram analisadas em reações separadas e em duplicata. Só foram diagnosticados como fetos masculinos quando foi emitido sinal em ambas as duplicatas. Além disso, em toda reação realizada, utilizam-se dois controles positivos (DNA de gestação de feto do sexo masculino), dois controles negativos (DNA de feto do sexo feminino), além do NTC (no template control), que é utilizado para saber se houve contaminação em algum dos reagentes durante o procedimento da reação. O tempo médio para realizar a metodologia é de aproximadamente três horas.

\section{Resultados}

Foram realizados 79 exames de DNA fetal do plasma materno de 52 gestantes. As 5 pacientes que evoluíram para aborto foram excluídas, uma vez que não houve meios de se confirmar o sexo fetal. A taxa de acerto variou de acordo com a idade gestacional (Tabela 1), porém, em todos os exames cujo resultado indicou feto do sexo masculino não houve falha diagnóstica. Em apenas três dos 79 exames ocorreu discordância no diagnóstico do sexo fetal. Em todas as ocasiões, os exames foram rotulados como falso-negativos, desde que o resultado identificou sexo feminino quando na verdade o feto era do sexo masculino. Os exames foram repetidos em aproximadamente 15\% dos casos pelo fato de os resultados terem sido inconclusivos.

Tabela 1 - Correlação do sexo fetal com a idade gestacional e índice de acerto.

\begin{tabular}{|c|c|c|c|c|c|c|c|}
\hline $\begin{array}{l}\text { Idade } \\
\text { gestacional }\end{array}$ & Feminino & Masculino & $\begin{array}{c}\text { Porcentagem } \\
\text { de acerto }\end{array}$ & Sensibilidade & Especificidade & VPP & VPN \\
\hline 5 semanas & 13 & 14 & $92,6 \%$ & $87 \%$ & $100 \%$ & $100 \%$ & $84 \%$ \\
\hline \multirow[t]{2}{*}{$\geq 7$ semanas } & 17 & 12 & $100 \%$ & $100 \%$ & $100 \%$ & $100 \%$ & $100 \%$ \\
\hline & 40 & 39 & - & - & - & - & - \\
\hline
\end{tabular}

VPN - Valor preditivo negativo.

VPP - Valor preditivo positivo.

$\mathrm{Na} 5^{\mathrm{a}}$ semana de gestação foram realizados 30 exames, dos quais três evoluíram para aborto, e em dois exames os resultados foram discordantes, gerando índice de acerto de 92,6\% (25 em 27 casos), conferindo sensibilidade de $87 \%$ (IC 95\%; $0,61-0,98$ ) e valor preditivo negativo de 0,84 (IC $95 \%$; 0,54-0,98). Na $6^{\circ}$ semana de gestação, dois dos 25 exames evoluíram para aborto e apenas um 
dos 23 exames foi discordante, determinando porcentagem de acerto de $95,6 \%$, sensibilidade de $92 \%$ (IC 95\%; 0,66-0,99) e valor preditivo negativo de 90\% (IC 95\%; 0,55-0,99 casos). Podemos destacar que todos os exames coletados a partir da $7^{\mathrm{a}}$ semana tiveram seus resultados confirmados pela ultra-sonografia (29 de 29). Além disso, independente da idade gestacional, a especificidade do exame foi de $100 \%$, gerando valor preditivo positivo de $100 \%$.

\section{Discussão}

Os resultados do presente estudo coincidem com os da literatura, que mostram indices de acerto da técnica superior a $97 \%$ quando o exame é realizado a partir da $7^{\mathrm{a}}$ semana de gestação ${ }^{13}$. Neste artigo, em que foram avaliadas 302 gestantes com idade gestacional entre 7 e 16 semanas, e se usou a mesma seqüência genômica utilizada nesse trabalho (DYS-14), foi encontrado índice de acerto para o sexo masculino de $97,2 \%$ (139 de 143 gestantes). O motivo pelo qual não se detectou o fragmento do cromossomo Y no plasma dessas quatro gestantes que apresentavam fetos do sexo masculino ainda é obscuro. Sabe-se que conforme evolui a idade gestacional, a concentração de DNA fetal no sangue materno aumenta ${ }^{8}$. Portanto, quanto maior a idade gestacional, maior a sensibilidade e mais fácil seria diagnosticar o sexo fetal. Entretanto, importantes oscilações nas concentrações de DNA fetal durante a gestação não podem ser excluídas.

A novidade desse trabalho é a possibilidade de se detectar o sexo fetal a partir da $5^{\mathrm{a}}$ semana de gestação com grande margem de confiança, uma vez que os estudos anteriores descritos estabeleceram a sétima semana como o tempo mínimo para a determinação do sexo fetal. Apenas um trabalho avaliou plasma de gestantes na $5^{\mathrm{a}}$ semana de gestação, porém com amostra de apenas dois testes e indice de acerto de $50 \%{ }^{19}$. Outra peculiaridade é o fato de que todas as gestantes que participaram desse estudo engravidaram por meio de fertilização in vitro (FIV). Tal fato confere maior precisão na idade gestacional. Atualmente sabe-se que as pacientes que engravidam naturalmente ou por FIV apresentam a mesma concentração de DNA fetal circulante no plasma ${ }^{20}$. Entre os casos em que não houve concordância do resultado do exame com o sexo fetal, o plasma havia sido coletado com idade gestacional precoce $\left(5^{\mathrm{a}}\right.$ e $6^{\mathrm{a}}$ semanas), o que nos leva a crer que a quantidade de DNA fetal circulante no sangue materno era insuficiente para a detec- ção. Além disso, o diagnóstico do sexo fetal correto foi possivel com o uso de novo exame em idade gestacional mais avançada.

Além da possível correlação entre a concentração do DNA fetal no sangue materno e a presença de aneuploidias fetais, o aumento da concentração do DNA fetal poderia também estar relacionado com distúrbios como pré-eclampsia, hiperêmese gravídica e algumas doenças relacionadas com a placenta ${ }^{17,18-21}$. Nossos dados preliminares de quantificação do cromossomo Y na $5^{a}$ e $6^{\mathrm{a}}$ semanas de gestação mostram que a média é de menos de 10 cópias genômicas por mililitro $(\mathrm{mL})$ de plasma, ou seja, está sendo detectada uma única cópia por reação, mostrando a sensibilidade do método aplicado.

A definição do sexo fetal pode ser muito útil para o manejo das doenças genéticas ligadas ao cromossomo X, como é o caso, por exemplo, da sindrome do X-frágil e hemofilia. O diagnóstico precoce do sexo fetal pode ajudar principalmente na ansiedade dos pais que estão sob um risco genético reprodutivo. Dessa mesma forma, o exame pode ser ferramenta valiosa nas clínicas de reprodução assistida para obtenção do diagnóstico genético pré-implantação de embriões com doenças ligadas ao sexo. Precocemente ( $5^{\mathrm{a}}$ semana), pode-se confirmar o sexo do feto, não havendo a necessidade da realização de exame invasivo como é a coleta de vilo ( $11^{\mathrm{a}}$ semana) ou líquido amniótico ( $16^{\mathrm{a}}$ semana). Outra utilidade do exame é o caso de risco de recorrência de hiperplasia congênita de supra-renal quando se usa corticosteroidoterapia como esquema terapêutico profilático logo no inicio da gestação para prevenir a possivel virilização dos fetos femininos afetados. Em fetos do sexo masculino, não há necessidade de tratamento, evitando-se assim, o uso desnecessário da medicação que pode gerar efeitos colaterais para a gestante ${ }^{16,21}$.

Em conclusão, o diagnóstico do sexo fetal a partir da $5^{a}$ semana de gestação pela técnica de PCR em tempo real apresenta boa sensibilidade e excelente especificidade. Entretanto, nos casos em que o resultado foi do sexo feminino, mas com a idade da gestação entre $5^{\mathrm{a}}$ e a $6^{\mathrm{a}}$ semana, recomenda-se que o exame seja repetido da $7^{\mathrm{a}}$ semana em diante para uma maior precisão diagnóstica.

\section{Referências}

1. Steele MW, Breg WR Jr. Chromosome analysis of human amniotic-fluid cells. Lancet. 1966;1(7434):3835 . 
2. Ogilvie CM, Donaghue C, Fox SP, Docherty Z, Mann K. Rapid prenatal diagnosis of aneuploidy using quantitative fluorescence-PCR (QF-PCR). J Histochem Cytochem. 2005;53(3):285-8.

3. El Mouatassim S, Becker M, Kuzio S, Ronsin C, Gil $\mathrm{S}$, Nouchy M, et al. Prenatal diagnosis of common aneuploidies using multiplex quantitative fluorescent polymerase chain reaction. Fetal Diagn Ther. 2004;19(6):496-503.

4. Nicolini U, Lalatta F, Natacci F, Curcio C, Bui TH. The introduction of QF-PCR in prenatal diagnosis of fetal aneuploidies: time for reconsideration. Hum Reprod Update. 2004;10(6):541-8.

5. Adinolfi M, Sherlock J, Pertl B. Rapid detection of selected aneuploidies by quantitative fluorescent PCR. Bioessays. 1995;17(7):661-4.

6. Walknowska J, Conte FA, Grumbach MM. Practical and theoretical implications of fetal-maternal lymphocyte transfer. Lancet. 1969;1(7606):1119-22.

7. Lo YM, Corbetta N, Chamberlain PF, Rai V, Sargent IL, Redman CW, et al. Presence of fetal DNA in maternal plasma and serum. Lancet. 1997;350(9076):485-7.

8. Lo YM, Tein MS, Lau TK, Haines CJ, Leung TN, Poon $P M$, et al. Quantitative analysis of fetal DNA in maternal plasma and serum: implications for noninvasive prenatal diagnosis. Am J Hum Genet. 1998;62(4):768-75.

9. Levi JE, Wendel S, Takaoka DT. Determinação prénatal do sexo fetal por meio da análise de DNA no plasma materno. Rev Bras Ginecol Obstet. 2003;25(9):687-90.

10. Bianchi DW, Williams JM, Sullivan LM, Hanson FW, Klinger KW, Shuber AP. PCR quantitation of fetal cells in maternal blood in normal and aneuploid pregnancies. Am J Hum Genet. 1997;61(4):822-9.

11. Wataganara T, LeShane ES, Farina A, Messerlian GM, Lee T, Canick JA, et al. Maternal serum cellfree fetal DNA levels are increased in cases of trisomy 13 but not trisomy 18 . Hum Genet. 2003;112(2):204-8.
12. Lo YM, Lau TK, Zhang J, Leung TN, Chang AM, Hjelm $\mathrm{NM}$, et al. Increased fetal DNA concentrations in the plasma of pregnant women carrying fetuses with trisomy 21. Clin Chem. 1999;45(10):1747-51.

13. Sekizawa A, Kondo T, Iwasaki M, Watanabe A, Jimbo $M$, Saito $H$, et al. Accuracy of fetal gender determination by analysis of DNA in maternal plasma. Clin Chem. 2001;47(10):1856-8.

14. Costa JM, Benachi A, Gautier E, Jouannic JM, Ernault P, Dumez Y. First-trimester fetal sex determination in maternal serum using real-time PCR. Prenat Diagn. 2001;21(12):1070-4.

15. Honda H, Miharu N, Ohashi Y, Samura O, Kinutani M, Hara T, et al. Fetal gender determination in early pregnancy through qualitative and quantitative analysis of fetal DNA in maternal serum. Hum Genet. 2002;110(1):75-9.

16. Rijnders RJ, Christiaens GC, Bossers B, van der Smagt JJ, van der Schoot CE, de Haas M. Clinical applications of cell-free fetal DNA from maternal plasma. Obstet Gynecol. 2004;103(1):157-64.

17. Sekizawa A, Jimbo M, Saito H, Iwasaki M, Sugito Y, Yukimoto $Y$, et al. Increased cell-free fetal DNA in plasma of two women with invasive placenta. Clin Chem. 2002;48(2):353-4.

18. Sekizawa A, Sugito Y, Iwasaki M, Watanabe A, Jimbo M, Hoshi S, et al. Cell-free fetal DNA is increased in plasma of women with hyperemesis gravidarum. Clin Chem. 2001;47(12):2164-5.

19. Rijnders RJ, Van Der Luijt RB, Peters ED, Goeree JK, Van Der Schoot CE, Ploos Van Amstel JK, et al. Earliest gestational age for fetal sexing in cell-free maternal plasma. Prenat Diagn. 2003;23(13):1042-4.

20.Pan PD, Peter I, Lambert-Messerlian GM, Canick JA, Bianchi DW, Johnson KL. Cell-free fetal DNA levels in pregnancies conceived by IVF. Hum Reprod. 2005;20(11):3152-6.

21.Lo YM. Recent advances in fetal nucleic acids in maternal plasma. J Histochem Cytochem. 2005;53(3):293-6. 